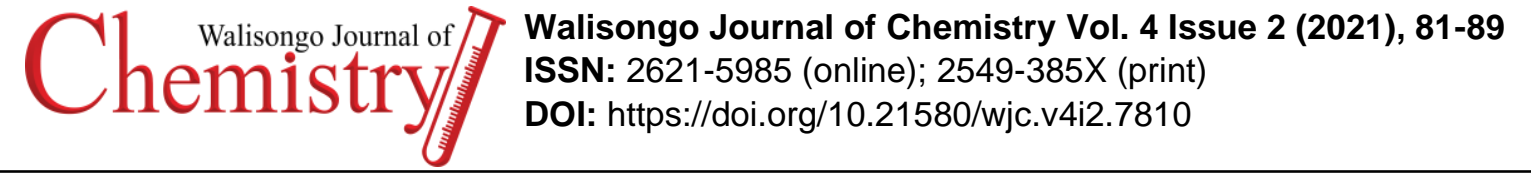

\section{Production, Determination of Proximate and Essential Minerals of Tembakul Fish Flour (Boleophthalmus Sp.) with Variations of Processing Methods}

\author{
Warsidah*, Titi muhartati, Dwi Imam Prayitno \\ Department of Marine Science, Faculty of Math and Science, Universitas Tanjungpura, \\ Pontianak, Indonesia \\ *E-mail: warsidah@fmipa.untan.ac.id
}

Received: 6 March 2021; Accepted: 14 October 2021; Published: 15 December 2021

\begin{abstract}
The Tembakul fish (Mudskipper) is one of the unique fauna resembling amphibian fish that can adapt to two different natural conditions. Boleopthalmus sp is one of three types of Mudskipper that inhabit the mangrove ecosystem in Mempawah. The purpose of this study was to produce fishmeal from Mudskipper Boleopthalmus sp and determine the nutritional content in the form of proximate and essential minerals based on variations in drying treatment before the flouring process. The study was carried out in November-February 2021. Samples were obtained by collecting randomly the Mempawah mangrove area and processed with five different treatments or preparations for flour processing, namely drying with salt, drying without salt, frying with oil, frying without oil, and drying with oven. Nutrient content in the form of proximate in fresh Boleopthalmus sp is fat (0.1\%), protein (20.67\%), water (81.02\%) and ash (1.69\%), with phosphorus mineral content (2.06\%), calcium $(1.20 \%)$ and iron (259.16 ppm). From these five preparations for processing the fishmeal, it showed that fishmeal was processed by drying without salt before being floured with the flour yield (20\%), fat content (2.18\%), protein content (68.7\%), moisture content (15.27\%), and ash content (9.17\%).
\end{abstract}

Keywords: Boleopthalmus sp.; fishmeal; nutrition; essential minerals

\section{Introduction}

Tembakul Fish (mudskipper) is a fish that is commonly found in mangrove ecosystems. According to Gosal et al. (2013), the mudskipper is unique fish because it can adapt to two different habitats. This fish is similar to amphibians because of its ability to last longer on the surface of the water and in the mud.

Currently, mudskippers have been widely cooked as a side dish in food menus, especially in foreign restaurants such as China and Japan. Even Korea has developed mudskippers into ornamental fish (Sunarni and Maturbongs, 2017). Several studies on mudskippers have been reported. Purwaningsih et al. (2014) reported that fresh Mudskipper contains important components such as $7.91 \%$ protein, $0.46 \%$ fat, $3.82 \%$ ash, and $72.80 \%$ water. Meanwhile, in a different location, it was reported that the nutritional content (proximate) of fresh mudskipper meat (Periophthalmodon schlosseri) from the mangrove ecosystem in the Lima Laras Village, Tanjung Tiram District, North Sumatra was $92.83 \%$ protein, $4.54 \%$ ash, fat 
$1.13 \%$, and $1.50 \%$ carbohydrates were calculated from the dry weight of the sample (Girsang et al., 2018). The nutritional content of fresh Mudskipper varies based on the species, environment, and different processing. Yurinatari et al. (2020) reported that the mudskipper fishmeal (Periopthalmus minutus) was taken from the water in Rantau Prapat city, North Sumatra, with the steaming process first, contained $16.56 \%$ yield, $77.96 \%$ protein, $5.23 \%$ water, $1.48 \%$ fat, and $13.67 \%$ ash.

There are so many mudskippers in the mangrove ecosystem, but it has not been utilized optimally because of the lack of public knowledge about the nutritional content, utilization, and processing. The meat and fishmeal of mudskipper in Indonesia are mostly utilized as components in the manufacture of feed in aquaculture because they have a relatively high protein content needed for aquaculture products. This is the basis for the determination of nutrition including proximate and essential minerals in mudskipper fishmeal that were previously treated in the form of different drying methods before the flouring process.

The purpose of this research is to produce fishmeal from mudskipper Boleopthalmus $s p$ and determine the nutritional content in the form of proximate and essential minerals based on variations in drying treatment before the flouring process.

\section{Research Method}

Tools and Materials

The tools used in this research are analytical balance (Ohaus), stopwatch, oven (Memmert), filter paper, measuring cylinder, dropper pipette, soxhlet, boiling flask, Erlenmeyer flask, test tube, test tube clamp, porcelain crucible, one Kjeldahl kit, distillator, desiccator and UV-Vis spectrophotometer HACH DR 3900, atomic absorption spectrophotometer AMT3802AA.

The materials used are mudskippers, E-Merck n-hexane solvent, clean water, distilled water, E-Merck $\mathrm{H}_{2} \mathrm{SO}_{4}$, E-Merck $\mathrm{NaOH}$, E-Merck $\mathrm{HCl}$, E-Merck $\mathrm{H}_{2} \mathrm{BO}_{3}$, E-Merck diethyl ether, $\mathrm{PP}$ indicator, $\mathrm{Cu}$ complex, $\mathrm{E}$ Merck concentrated $\mathrm{H}_{2} \mathrm{SO}_{4}$, E-Merck $\mathrm{H}_{2} \mathrm{O}_{2}$, EMerck $\mathrm{Na}_{2} \mathrm{~S}_{2} \mathrm{O}_{3}$, and E-Merck chloroform.

\section{Making Fishmeal (Girsang et al., 2018)}

Fishmeal is made by five different processes, namely: fresh mudskipper fish (A0), sun drying without salt (A1), drying in the oven (A2), frying with oil (A3), drying with salt (A4), frying without oil (A5). Drying with or without salt was carried out for 2 days and dried under sunlight for 8 hours a day. Before drying in the oven, the fish was boiled for 10 minutes first. After that, it was dried in the oven for 4 hours at a temperature of $55^{\circ} \mathrm{C}$. Size reduction was carried out by using a dry blender. After blending, the fishmeal was sifted by using a flour sifter first.

\section{Analysis of Protein Content (BSN, 2006)}

Protein analysis was carried out by providing 2 grams of the sample on a filter paper, then folded and put into a Kjeldahl flask and added two catalyst tablets and glass beads. Furthermore, $15 \mathrm{ml}$ of concentrated $\mathrm{H}_{2} \mathrm{SO}_{4}$ and $3 \mathrm{ml}$ of $\mathrm{H}_{2} \mathrm{O}_{2}$ were added slowly and allowed to stand for 10 minutes in the acid chamber. Destruct at $410^{\circ} \mathrm{C}$ for 2 hours until the solution became clear, then allowed to stand until it reached room temperature, and then added $75 \mathrm{ml}$ of distilled water. Add 5-7 drops of phenolphthalein indicator and $50 \% \mathrm{NaOH}$ until a pink solution was formed. Then fill the Erlenmeyer with $4 \% \mathrm{H}_{2} \mathrm{BO}_{3}$ as much as $25 \mathrm{ml}$ and add the red-blue methylene indicator until the blue solution was accommodated and bound with $\mathrm{H}_{2} \mathrm{BO}_{3}$ until a green solution was formed. The flask containing the sample is mounted on a steam distillation apparatus. After that, $75 \mathrm{ml}$ of $\mathrm{Na}_{2} \mathrm{~S}_{2} \mathrm{O}_{3}$ solution was added and distilled for 15 minutes. The distillate was collected by using an Erlenmeyer to a volume of $150 \mathrm{ml}$. Titrate the results of the distillation by adding a $0.2 \mathrm{~N}$ of $\mathrm{HCl}$ solution until it turns blue. Do the same for blanks without adding samples. 
The formula for protein content (\% protein) is:

$\frac{(\mathrm{VA}-\mathrm{VB}) \mathrm{HCL} \times \mathrm{N} \mathrm{HCL} \times 14,007 \times 6,25}{\mathrm{~W} \times 1000} \times 100 \%$

Notes: VA: volume of $\mathrm{HCl}$ for sample titration (ml), VB: volume of $\mathrm{HCl}$ for blank titration, N: normality of standard $\mathrm{HCl}$ used, 14.007: atomic weight of nitrogen, and 6.25: fish protein conversion factor.

\section{Analysis of Fat Content (BSN, 2006)}

The first step was drying the boiling flask in the oven for 1 hour at a temperature of $105-110^{\circ} \mathrm{C}$ and weighing the weight (W2). Weigh the sample as much as 2 grams (W1) by using filter paper and then insert it into boiling flask. Put $150 \mathrm{ml}$ of chloroform into the boiling flask, then the boiling flask was assembled into the Soxhlet tube extractor. The fat extraction process was carried out for 8 hours at a temperature of $60^{\circ} \mathrm{C}$. Then, the mixture of fat and chloroform was evaporated until dry. Dry the boiling flask in the oven for 2 hours at a temperature of $105^{\circ} \mathrm{C}$ so that the remaining chloroform and water vapor disappeared. Chill the boiling flask filled with fat in a desiccator for 30 minutes. Then, it was weighed until it had constant weight (W3). The formula for fat content is:

Fat Content $(\%)=\frac{(\mathrm{W} 3-\mathrm{W} 2)}{\mathrm{W} 1} \times 100 \%$

Notes: W3: weight of the sample (grams), W2: weight of boiling flask (grams), W1: Weight of boiling flask containing sample (grams).

\section{Analysis of Moisture Content (BSN, 2015)}

The empty petri dish was dried by using the oven for 2 hours at a temperature of $105^{\circ} \mathrm{C}$. Then, it was chilled for 30 minutes until it reached room temperature by using a desiccator. Next, weigh the empty petri dish (A gram). Provide 2 grams of fishmeal weighed using a petri dish that had been dried in the oven (B gram). Place the petri dish containing the sample in an oven for 24 hours at a temperature of $105^{\circ} \mathrm{C}$ and chill it for 30 minutes using a desiccator, and then weigh it until the weight is constant (C grams). The formula for moisture content is:

Moisture content $(\%)=\frac{B-C}{B-A} \times 100 \%$

Notes: A: petri dish containing samples (grams), B: empty petri dish (grams), C: Petri dish containing processed samples (grams).

Analysis of Ash Content (BSN, 2010)

The empty porcelain dish was placed into the muffle furnace. The temperature of the furnace was increased gradually until it reached $550^{\circ} \mathrm{C}$. This temperature was maintained for 24 hours. After that, the temperature of the muffle furnace was lowered to $40^{\circ} \mathrm{C}$, the porcelain dish was then removed and chilled for 30 minutes by using a desiccator. The empty porcelain dish was weighed until it had constant weight (A). As much as 2 grams of the sample was put into a porcelain dish and put in an oven for 24 hours at a temperature of $100^{\circ} \mathrm{C}$, and put back into the furnace, and raised the temperature to $550^{\circ} \mathrm{C}$, and left it for 24 hours until the ash turned white. The temperature of the furnace was lowered to $40^{\circ} \mathrm{C}$, the porcelain dish was removed by using clamps and put into a desiccator for 30 minutes, and then chilled and weighed the sample to have a constant weight (B grams). The formula for ash content is:

Ash Content $(\%)=\frac{B-A}{\text { sampel weight }} \times 100 \%$

Notes: A: Empty porcelain dish (grams), B: Weight of porcelain dish containing sample (grams).

\section{Analysis of Mineral Content (Calcium, Phosphorus, and Iron)}

The fishmeal that provides the best nutritional test with the largest indicator of protein content will be continued for analysis of mineral content including Calcium, Phosphorus, and Iron. 
As many as five grams of fishmeal A1 (sundried without salt) were put into a measuring cylinder and added $10 \mathrm{ml}$ of $\mathrm{HCl} 1$ $\mathrm{N}$. The mixture was homogenized and extracted in the refrigerator for 24 hours. It was taken by pipette $2 \mathrm{ml}$ of the extract, after that, it was adjusted with distilled water until the volume became $50 \mathrm{ml}$. The filtrate obtained was then divided into two bottles; $25 \mathrm{ml}$ was put in a bottle for the calcium and iron test and $25 \mathrm{ml}$ for the phosphorus test. Calcium and iron test were carried out by using an AAS spectrophotometer with a wavelength of $420 \mathrm{~nm}$. Phosphorus test was carried out by using a UV-Vis spectrophotometer at a wavelength of 400 $\mathrm{nm}$. The formula for essential mineral analysis is:

Mineral $(\%)=\frac{K \cdot \operatorname{sampel}\left(\frac{\mathrm{mg}}{\mathrm{L}}\right) \times \mathrm{V} \cdot \text { Sampel }(\mathrm{ml})}{\text { Berat sampel }(\mathrm{g})}$

\section{Results and Discussion}

The intertidal zone is an area that is very suitable for the survival of mudskippers. There will be much of this fish found highly at low tide and lowly at high tide (Akbar et al., 2020).

Boleopthalmus sp is one of three types of mudskipper that inhabit the mangrove ecosystem in Mempawah. In this study, the production of fishmeal from Boleopthalmus $s p$ was carried out which was dried with different treatments first before being floured.

\section{Physical Appearance and Fishmeal Yield}

Before processing the mudskipper fishmeal, the fish meat was separated first from the bones and innards. Furthermore, five different treatments were made in processing the sample mudskipper Boleopthalmus $s p$. before the flouring was carried out. As the control item was the fresh meat of the mudskipper without any treatment at all.

According to Afrianto and Liviawati (2005), good quality fishmeal must have some characteristics such as uniformly sized granules, no fish eyes, bone components and strange matters, clean and smooth in color, and has a fishy smell like the smell of fish.

Yield is the percentage of the resulting product, namely the ratio of the product produced to the raw materials. The average yield of the fishmeal produced can be seen in Table 1.

The highest yield of fishmeal was found in sample A5 of $36.5 \%$. It was the mudskipper as a sample dried first by frying without oil. Sample A1 had the smallest percentage of flour yield, which was $20 \%$. Sample A1 was a sun-dried without salt sample.

Table 1. The yield of mudskipper fishmeal

\begin{tabular}{cccc}
\hline Treatment & $\begin{array}{c}\text { First } \\
\text { Weight } \\
\text { (g) }\end{array}$ & $\begin{array}{c}\text { Last } \\
\text { Weight } \\
(\mathrm{g})\end{array}$ & $\begin{array}{c}\text { Percentage } \\
\%\end{array}$ \\
\hline A1 & 110 & 22 & 20 \\
A2 & 110 & 30.25 & 27.5 \\
A3 & 110 & 36.3 & 33 \\
A4 & 110 & 40 & 36.3 \\
A5 & 110 & 40.155 & 36.5 \\
\hline
\end{tabular}

Notes:

A0 $=$ fresh meat of mudskipper

A1 = sun-dried without salt

$\mathrm{A} 2$ = dried by oven

A3 $=$ fried with oil

A4 $=$ dried with salt

A5 $=$ fried without oil

The absence of salt in sample A1 caused reducing the water withdrawal from fish tissue, which has the potential to cause physical and chemical abnormalities, such as texture (Adawyah, 2007). According to Hall (1992), the presence of salt in fermented or salted food products can cause a decrease in the quality of the texture because of oxidation.

Fishmeal products with A1 treatment produced fishmeal that had a faded brown color as well as fishmeal A4 one. Fish meat with treatment A3 and A5 produced light dark brown fishmeal. While fish meat with treatment A2 produced light brown color fishmeal. From these results, it is known that the color of fishmeal that is processed at high temperatures will have a darker color. 
According to Girsang et al.( 2018), the longer the heating process is carried out, the more Melanoidins will be formed and the darker the brown color will be. This reaction is known as the Maillard reaction.

Table 2. The fat content of fishmeal

\begin{tabular}{cc}
\hline Treatment & Fat Content (\%) \\
\hline A0 & 0.1 \\
A1 & 2.18 \\
A2 & 1.51 \\
A3 & 25.98 \\
A4 & 0.61 \\
A5 & 1.77 \\
\hline
\end{tabular}

Fishmeal with treatment A4 has the lowest fat content of $0.61 \%$ and fishmeal with treatment $\mathrm{A} 3$ has the highest fat content of $25.98 \%$. According to Zahra et al. (2013), frying is a type of drying of foodstuffs by using the heat of frying oil as a medium. The increase of fat content in process A3 was caused by the loss of moisture content and the accumulation of oil during processing. Azka et al. (2019) reported that the low-fat content in fishmeal with the process A4 was due to the influence of salting. The salt acts as a catalyst in the oxidation process of fish fat so that the fat will be oxidized and have a reduction in fat content.

The fat content of mudskipper fishmeal is not much different from other commercial fish. The best fat content of this fishmeal is in the drying process with salt, which is $0.61 \%$. The fat content is not much different from the fat content of Tuna meat of 0.51\% (Hadinoto \& Idrus, 2018), snakehead fish of $1.69 \%$ (Suwandi et al., 2014), male long-jawed mackerel of $1.53 \%$ (Salamah et al., 2004), and Spanish mackerel fish 1.5\% (Purwaningsih et al., 2014).

Based on the SNI 01-2715-1996, the quality requirement of fat content (\%) in fishmeal is $8 \%$. In this study, the fat content of fresh mudskipper meat and its fishmeal met the Indonesian National Standard (SNI) except those are processed by frying. The best process of this product that produces the lowest fat content in this research is the mudskipper fishmeal made by sun-dried with salt process (fermented or salted). Table 3. The protein content of fishmeal

\begin{tabular}{cc}
\hline Treatment & Protein content $(\%)$ \\
\hline A0 & 20.67 \\
A1 & 68.7 \\
A2 & 60.64 \\
A3 & 61.09 \\
A4 & 32.33 \\
A5 & 58.34 \\
\hline
\end{tabular}

The highest protein content is in process $\mathrm{A} 1$, which is $68.70 \%$. The lowest protein content is in the process $A 4$, which is $20.67 \%$. The protein content in process A1 was high because the protein in the fishmeal was not being denatured. The drying process had a relatively low temperature ranging from $27-35^{\circ} \mathrm{C}$. Changes in protein content in fishmeal are influenced by temperature and length of processing time. The lower the temperature, the higher the protein content in the fishmeal. The use of higher temperatures will cause protein denaturation and other nutritional content (Girsang et al., 2018).

According to Puspita et al. (2019), the addition of salt concentration can increase the protein content of foodstuffs. The absorption of salt by fish meat will denature the protein colloid solution so that coagulation occurs which frees water out of the fish meat. The protein content of mudskipper is quite high as much as other commercial fish. The following are some of the protein content of commercial fish, namely Tuna fish with a wet base of $28.34 \%$ (Hadinoto \& Idrus, 2018), Spanish mackerel fish of 19.73\% (Purwaningsih et al., 2014), and long-jawed mackerel of $19.74 \%$ (Salamah et al., 2004).

Based on the SNI 01-2715-1996, the fishmeal protein standard is $45-65 \%$. In this research, only one process did not meet the standard. It was fishmeal sun-dried with salt. The best processing method of fishmeal that produces the highest protein content was sun-dried without salt. 
Table 4. The moisture content of fishmeal

\begin{tabular}{cc}
\hline Treatment & Moisture content (\%) \\
\hline A0 & 81.02 \\
A1 & 15.27 \\
A2 & 24.58 \\
A3 & 13.87 \\
A4 & 34.9 \\
A5 & 43.15 \\
\hline
\end{tabular}

The highest moisture content is in process A5, which is $43.15 \%$. The lowest moisture content is in process $\mathrm{A} 3$, which is $13.87 \%$. The uneven heat received by the fish so that evaporation in the water is not optimal causes the high moisture content in the processing A5. Meanwhile, the heat of frying oil as a medium causes the low moisture content in processing A3. It releases water molecules from the fishmeal yield and evaporates when the frying process is carried out. The longer the heating is carried out in the foodstuffs, the less the moisture content will be. Several studies have reported the moisture content of some fresh fish and processed fish including wet basis of Tuna which has a moisture content of $71.73 \%$ (Hadinoto and Idrus, 2018), longjawed mackerel's wet basis of $83.15 \%$ (Salamah et al., 2004), and Spanish mackerel fish' wet basis of 76.4 5\% (Purwaningsih et al., 2014).

Based on SNI 01-2715-1996, the standard moisture content in fishmeal is 10$12 \%$. In this study, none of the fishmeal processes that produce moisture content meet the standard because the mudskippers live wild in the mangroves and their environment cannot be controlled like farmed fish. The soil in the mangrove environment tends to be lower than sea level so that the mudskippers are always in a wet/watery state even though the sea water is receding. It makes it difficult to dry the meat before being made into fishmeal. As a result, the fishmeal does not meet the required moisture content of the standard. In addition, a process that produces too low a moisture content will cause loss or decrease in the content of nutrients such as protein. High heating decomposes it and other important components evaporate along with the water.

Table 5. The ash content of fishmeal

\begin{tabular}{cc}
\hline Treatment & Ash content (\%) \\
\hline A0 & 81.02 \\
A1 & 15.27 \\
A2 & 24.58 \\
A3 & 13.87 \\
A4 & 34.9 \\
A5 & 43.15 \\
\hline
\end{tabular}

The mudskipper fishmeal in process A3 has the lowest ash content of $6.08 \%$ and process A4 has the highest ash content of $28.29 \%$. The ability of salt to hydrolyze water out of the fishmeal yield caused the high ash content in the A4 process. According to Purwaningsih et al. (2014), the addition of salt to a foodstuff will increase the ash content in it. Meanwhile, the low inorganic material in the fishmeal yield caused the low ash content in process A3.

According to Wahbi (2018), the ash content in a foodstuff shows the amount of mineral content contained in it. Determination of ash content plays a very important role in determining the nutritional value of a foodstuff. Ash is composed of various types of diverse minerals. According to Girsang et al. (2018), drying of the moisture content carried out on foodstuff will cause the remaining ingredients such as mineral elements or other inorganic substances to become a concentrate. Here are some of the ash content in commercial fish and other consumption fish. Tuna fish has 1.48\% (Hadinoto and Idrus, 2018) and Spanish mackerel fish has $1.52 \%$ (Purwaningsih et al., 2014).

Based on SNI 01-2715-1996, the standard ash content is $20-30 \%$. Based on the results of the tests, only the sun-dried process with salt meets the standard one.

\section{Essential mineral content}

From five types of treatment for drying fish meat before making fishmeal, sample A1 provided better performance and nutritional content than the other four types. 
Therefore, it continued to measure the essential mineral content of sample A1 including phosphorus, calcium, and iron.

Table 6. The essential mineral content of A1 fishmeal with sun-dried without salt process.

\begin{tabular}{ll}
\hline \multicolumn{1}{c}{ Mineral } & Value \\
\hline Fosfor (P) (\%) & 2.06 \\
Kalsium (Ca) (\%) & 1.20 \\
Besi (Fe) (ppm) & 259.16 \\
\hline
\end{tabular}

According to Imra et al. (2019), Phosphorus (F) is one of the elements (minerals) needed by humans. It has a role in composing bones and tooth structure. Based on Dewan Standarisasi Nasional (1996) SNI 01-2715-1996, the maximum standard of phosphorus content in foodstuffs is 1.6 $4.7 \%$. Based on the analysis of phosphorus in the fishmeal, it was found that the phosphorus content was $2.06 \%$. The content met the requirements of the 1996 SNI standard.

Calcium (Ca) is a nutrient needed by living things, especially for humans. The optimal use of $\mathrm{Ca}$ in the body is influenced by the phosphorus content. When phosphorus levels in the body increase and decrease, it will affect the excretion of calcium (Ca). Calcium plays an important role in the process of bone formation in the human body. Based on the SNI 01-2715-1996, the maximum calcium content in foodstuffs is 2.4 - 7.0\%. In this test, the calcium content was obtained at $1.20 \%$. it means that it does not meet the SNI for fishmeal products (Ramayulis et al., 2011).

Another mineral needed by humans is iron. Iron is a trace element and is monitored in small amounts in the body. With the limited amount of iron in the body, the person must provide iron through eating food (Mudjajanto et al., 2015). According to Salamah et al. (2004), the human body requires iron as much as $4.7-18.29 \mathrm{mg} /$ day depending on age and gender. The iron content in the fishmeal in this study was $259.16 \mathrm{ppm}$ or $0.2519 \mathrm{mg} / \mathrm{gram}$. Based on SNI 2715:2013, the minimum iron quality requirement for fishmeal is $16.6 \mathrm{mg} / \mathrm{gram}$.
The iron content in this fishmeal does not meet the SNI quality standards.

\section{Conclusion}

The nutritional content of mudskipper fishmeal with various processing did not have a significant difference to fresh meat fish qualitatively. However, quantitatively, it did. Nutrient content tends to increase after processing. Good fishmeal is produced by sun-dried without salt method. This method produces a yield of $20 \%$, fat content of $2.18 \%$, protein content of $68.7 \%$, moisture content of $15.27 \%$, and ash content of 9.17 $\%$. Mudskipper fishmeal contains three essential minerals, namely Calcium, Phosphorus, and Iron. Calcium content was $1.20 \%$, Phosphorus was $2.06 \%$, and Iron was 259.16 ppm.

\section{References}

Adawyah, R. (2007). Pengolahan dan pengawetan ikan. In Bumi Aksara. Jakarta (Vol. 159). PT. Bumi Aksara.

Afrianto, E., \& Liviawati, E. (2005). Pakan Ikan Kanisius. In Yogyakarta. Hal. Kanisius.

Akbar, N., Bode, I. D., Baksir, A., Tahir, I., Paembonan, R. E., Marus, I., \& Wibowo, E. S. (2020). Distribusi dan karakteristik habitat ikan tembakul (Gobiidae sp) di pesisir Pantai Pulau Ternate Provinsi Maluku Utara. Jurnal Maritim, 1(2), 49-58.

Azka, A., Ratrinia, P. W., Hasibuan, N. E., \& Harahap, K. S. (2019). PENGARUH PERBEDAAAN KONSENTRASI GARAM TERHADAP KOMPOSISI PROKSIMAT IKAN BIANG (Ilisha elongata) ASIN KERING. Aurelia Journal, 1(1), 24. https://doi.org/10.15578/aj.v1i1.837 8

Badan Standardisasi Nasional. (2006). Cara Uji Kimia-Bagian 3: Penentuan Kadar Lemak Total Pada Produk Perikanan. Badan Standarisasi Nasional.

Badan Standardisasi Nasional. (2010). Cara Uji Kimia-Bagian 1: Penentuan Kadar Abu Dan Abu Tak Larut Dalam Asam Pada Produk Perikanan. 
Badan Standardisasi Nasional. (2015). Cara Uji Kimia-Bagian 2: Penentuan Kadar Air pada Produk Perikanan. Badan Standarisasi Nasional.

Badan Standarisasi Nasional. (2006). Cara uji kimia - Bagian 4: Penentuan kadar protein dengan metode total nitrogen pada produk perikanan. In Standar Nasional Indonesia. Badan Standarisasi Nasional.

Dewan Standarisasi Nasional. (1996). Tepung Ikan Bahan Baku Pakan. In Seminar Nasional Tahunan XII Hasil Penelitian Perikanan dan Kelautan (Vol. 1996, Issue 1). Dewan Standarisasi Nasional. 5/21/2018 Sni Tepung Ikan - slidepdf.com http://slidepdf.com/reader/full/snitepung-ikan

Girsang, E., Edison, \& Karnila, R. (2018). Analysis of Mudskipper (Periophthalmodon schlosseri) Chemical Content In Different Steaming Temperatures. Jurnal Online Mahasiswa, 5, 2018.

Gosal, L. M., Katili, D. Y., Singkoh, M. F., \& Tamanampo, J. E. (2013). Kebiasaan Makanan Ikan Gelodok (Periophthalmus sp.) di Kawasan Mangrove Pantai Meras, Kecamatan Bunaken, Kota Manado, Sulawesi Utara (The Food Habit of Mudskipper Fish, Periophthalmus sp. in Mangrove Areas of Meras Beach, Bunaken District, Manado City, No. Jurnal Bios Logos, $3(2)$. https://doi.org/10.35799/jbl.3.2.201 3.4429

Hadinoto, S., \& Idrus, S. (2018). Proporsi dan Kadar Proksimat Bagian Tubuh Ikan Tuna Ekor Kuning (Thunnus albacares) Dari Perairan Maluku. Majalah BIAM, 14(2), 51. https://doi.org/10.29360/mb.v14i2.4 212

Hall, G. (1992). Fish processing technology. In Fisheries Research (Vol. 16, Issue 4). $\mathrm{VCH}$ Publisher. Inc.https://doi.org/10.1016/01657836(93)90147-y

Imra, I., Fadnan Akhmadi, M., \&
Maulianawati, D. (2019). Fortifikasi Kalsium dan Fosfor pada Crackers dengan Penambahan Tepung Tulang Ikan Bandeng (Chanos chanos) $<$ br $><$ i $>$ [Calcium and Phosfor Fortification of Crackers by Using Milkfish Bone (Chanos chanos)] $<\mathrm{i}>$. Jurnal Ilmiah Perikanan Dan Kelautan, 11(1), 49. https://doi.org/10.20473/jipk.v11i1. 11911

Mudjajanto, E. S., Kholilah, W., \& Amaliah, N. (2015). Nilai Gizi serta Daya Terima Biskuit dengan Penambahan Tepung Ikan Layang (Decapterus russelli) dan Ikan Selar (Caranx SP) (The Nutritional Value and Acceptability of Biscuits with the Fish Addition of Indian Scad (Decapterus russelli) and Trevally (Caranx. sp) Fishmeal). Jurnal Sains Terapan, 5(1), 26-39. https://doi.org/10.29244/jstsv.5.1.26 $-39$

Purwaningsih, S., Salamah, E., \& Dewantoro, R. (2014). Chemical Composition and Fatty Acids of Glodok Fish by High Thermal Processing. Jurnal Pengolahan Hasil Perikanan Indonesia, 17(2).

https://doi.org/10.17844/jphpi.v17i2 .8720

Puspita, D. A., Agustini, T. W., \& Purnamayati, L. (2019). Pengaruh Perbedaan Konsentrasi Garam terhadap Kadar Asam Glutamat Pada Bubuk Bekasam Ikan Lele (Clarias batracus). Jurnal Teknologi Pangan, 3(1), 110-115.

Ramayulis, R., Pramantara, I. D., \& Pangastuti, R. (2011). Asupan vitamin, mineral, rasio asupan kalsium dan fosfor dan hubungannya dengan kepadatan mineral tulang kalkaneus wanita. Jurnal Gizi Klinik Indonesia, $7(3)$,

115.https://doi.org/10.22146/ijcn.17 752

Salamah, E., Hendarwan, \& Yunizal. (2004). Studi tentang asam lemak omega-3 dari bagian-bagian tubuh ikan kembung laki-laki (. 8(2), 1-7. 
Sunarni, S., \& Maturbongs, M. R. (2017). Biodiversitas dan Kelimpahan Ikan Gelodok (Mudskipper) di Daerah Intertidal Pantai Payumb, Merauke. Prosiding Seminar Nasional Kemaritiman Dan Sumberdaya PulauPulau Kecil, 1(1), 125-131.

Suwandi, R.-, Nurjanah, - -, \& Winem, M.-. (2014). Proporsi Bagian Tubuh Dan Kadar Proksimat Ikan Gabus Pada Berbagai Ukuran. Jurnal Pengolahan Hasil Perikanan Indonesia, 17(1). https://doi.org/10.17844/jphpi.v17i1 .8134

Wahbi, M. O. H. (2018). JURNAL PROFIL ASAM AMINO IKAN TEMBAKUL ( Periophthalmus minutis ) Mahasiswa Fakultas Perikanan dan Kelautan Universitas Riau. Jurnal.

Yurinatari, Edison, \& Sukmiwati, M. (2020). Studi Komperatif Dengan Pemanasan yang Berbeda Terhadap Kandungan Gizi Ikan Tembakul.21(1), 1-9.

Zahra, S. L., Dwiloka, B., \& Mulyani, S. (2013). Pengaruh Penggunaan Minyak Goreng Berulang terhadap Perubahan Nilai Gizi dan Mutu Hedonik pada Ayam Goreng. Animal Agriculture Journal, 2(1), 253-260. 